\title{
Review on Various Types of Geopolymer Materials with the Environmental Impact Assessment.
}

\author{
Hariz Zain ${ }^{1, *}$, Mohd Mustafa Al Bakri Abdullah ${ }^{1,2}$, Kamarudin Hussin ${ }^{1,2}$, Nurliyana \\ Ariffin $^{1,2}$, and RIDHO Bayuaji ${ }^{3}$ \\ ${ }^{1}$ Faculty of Engineering Technology, Universiti Malaysia Perlis (UniMAP), Perlis, Malaysia \\ ${ }^{2}$ Center of Excellence Geopolymer and Green Technology (CEGeoGTech), Universiti Malaysia Perlis \\ (UniMAP), Malaysia \\ ${ }^{3}$ Civil Engineering Department, Institut Teknologi Sepuluh Nopember, Indonesia
}

\begin{abstract}
The development of green technology in the construction industry since 10 years ago is something to be proud of Malaysia. Several alternative geopolymer materials were invented in Malaysia such as fly ash, POFA, kaolin, metakaolin, and dolomite based geopolymer materials to achieve sustainable development especially in the building and construction sector. Those alternative materials are very important to replace the application of OPC, which is said to be the main cause of global warming. A review on the content of the chemical differences with the environmental impact resulting from the production of geopolymer is carried out in this study. In conclusion, fly ash based geopolymer material showed the best performance in terms of aluminosilicate content and also it is the best practice in the environmental protection applications for the moment. However, when compared with the OPC, fly ash geopolymer concrete was still able to reduce the effects of global warming potentials, but it is rather gave a negative impact on some aspects of the environment such as abiotic depletions, human toxicity, freshwater ecotoxicity, terrestrial ecotoxicity and acidification.
\end{abstract}

\section{Introduction}

The development of green technology in the construction industry since 10 years ago is something to be proud of Malaysia. It also involves and feedback on initiatives in the construction and development of geopolymer. The increment of environmental awareness in recent years around the world including Malaysia has led to a positive assessment of the environmental impact for building materials, in addition to their technical properties. As geopolymer concretes don't contain Portland cement and the powder binder used is typically an industrial waste or a minimally-processed natural material, they can have lower carbon dioxide emissions than classic concrete and be presented as environmental friendly. However, despite the release of carbon become the main criteria used in the assessment of environmental impacts, there are also other aspects that affect the environment, such as fresh

\footnotetext{
*Corresponding author: harizhijaureen@gmail.com
} 
water and marine ecotoxicity, human toxicity, ozone depletion, acidification, and eutrophication.

Geopolymer concrete had been introduced to reduce the environmental impacts. It is also showed good properties such as high compressive strength, low creep, good acid resistance and low shrinkage [1]. In addition, integrating green building materials into building projects can help to reduce the environmental impacts associated with the extraction, transport, processing, fabrication, installation, reuse, recycling, and disposal of these building industry source materials [2]. Attempts are being made to reduce $\mathrm{CO}_{2}$ emissions and lower the energy consumption. One of the alternatives to produce more environmentally friendly concrete is to replace the amount of OPC in concrete with by-product materials such as fly ash in the form of blended cement [3]. However, the major drawbacks of blended cements are low early strength. Another way to have environmentally friendly concrete, which can lower $\mathrm{CO}_{2}$ emission, is the development of inorganic alumino-silicate polymer, called geopolymer, synthesized from materials of geological origin or by-product materials such as fly ash that is rich in silicon and aluminum [4]. This paper reviews the comparisons of selected types of geopolymer based materials with their environmental impact assessment.

\section{The types of geopolymer materials}

Fly Ash. Fly ash is the residue from the combustion of coal which is widely available worldwide and lead to the anthropogenic pollution. Thus, fly ash-based geopolymer concrete is a good alternative to overcome the abundance of fly ash. Fly ash is rich in silicate and alumina, hence it reacts with alkaline solution to produce aluminosilicate gel that binds the aggregate to produce good concrete. In fly ash-based geopolymer concrete, the silica and the alumina present in the source materials are first induced by alkaline activators to form a gel known as aluminosilicate. The common materials used as alkaline solution in producing fly ash-based geopolymer are sodium silicate and potassium hydroxide [5].

Usually either of this material was mixed with sodium hydroxide to produce the alkaline solution and the molarity (M) of alkaline solution is 7 to $10 \mathrm{M}$ [5]. Abdul Aleem and Arumairaj [27] used to mix fly ash with $10 \mathrm{M}$ alkaline solution while Kawade et al. [28] varied the molarity of sodium silicate solution like $12 \mathrm{M}, 14 \mathrm{M}$ and $16 \mathrm{M}$.The alkaline solution was prepared a day before it is mixed with fly ash. Then, the materials are mixed together with fine aggregate and coarse aggregate to form concrete and curing process been done. To produce higher strength of geopolymer, the optimum sodium silicate to sodium hydroxide ratio was in the range of 0.67 to 1.00 . Meanwhile, the concentration of $\mathrm{NaOH}$ is in between 10 and $20 \mathrm{M}$ will give small effect on the strength [5-6].

Setting time for geopolymer depend on many factors such as composition of alkaline solution and ratio of alkaline liquid to fly ash by mass. However, the curing temperature is the most important factor for geopolymer. As the curing temperature increases, the setting time of concrete decreases [7]. During curing process, the geopolymer concrete experience polymerization process. Due to the temperature increment, polymerization become more rapid and the concrete can gain $70 \%$ of its strength within 3 to 4 hours of curing period [8].

Palm oil fuel ash (POFA). The large production of palm oil in Malaysia has made it become the second largest oil palm producer in the world on 2010, where 18.6 million metric tonnes of crude palm oil has been made [9]. However, waste from the palm oil industry also abundantly produced which caused criticism and complaint. Waste such as palm fibers, nut shells, palm kernel and empty fruit bunches are the solid waste that can be obtained from palm oil mill. Furthermore, these wastes were incinerated in boilers and from this process two types of oil palm ashes were produced which is boiler ash and palm oil fuel ash (POFA). 
Boiler ash can be obtained from the burning of oil palm fiber and palm kernel shells in the boiler where it consists of clinker and ash [10]. POFA is by-product from power plant that generate electricity which used palm fiber, shell and empty fruit bunches as fuel and burnt at $800-1000^{\circ} \mathrm{C}$ [11]. The production of boiler ash and POFA was estimated more than 4 million tonnes/year in Malaysia only [12]. In order to reduce environmental problems, palm oil ash has been utilized in many applications such as raw material for geopolymer composite, cement replacement in production of concrete, wastewater treatment and air purifier in cleaning atmospheric contaminants [9]. Compressive strength of cement paste containing pozzolan materials is contributed by hydration reaction, packing effect and pozzolanic reaction. Hydration reaction is the chemical between Portland cement and water as pozzolanic reaction silica compound and calcium hydroxide [11]. Moreover, packing effect is a proper arrangement of small particles which fill the voids and contribute to the increment of compressive strength [29,30]. Researchers Tangpagasit et al. [31] have to find the compressive strength due to packing effect and pozzolanic reaction use of insoluble material.

Kaolin. Kaolin is a fine clay, rich in kaolinite and used in ceramics. Frequently used aluminosilicate sources are of kaolinite, fly ash, callcined kaolin, and chemically synthesized kaolin. Geopolymers are synthesized by polycondensation below $100{ }^{\circ} \mathrm{C}$ at ambient pressure in an alkaline solution. In terms of past literatures, effects of calcined kaolin at high temperatures $\left(800-900{ }^{\circ} \mathrm{C}\right)$ towards properties of post obtained geopolymer have not been elaborately discussed [13].

Kaolin, most versatile white mineral that possess outstanding properties such as chemically unreactive over a wide range of $\mathrm{pH}$ and good covering powder when used as a pigment or extender. Secondary kaolins that are fine had been used as gloss materials due to their smaller particle size. Whereas platy kaolin particles, provides excellent coating opacity and printability [14]. Kaolin is also soft, non-abrasive, poor heat and electric conductor. The compressive strength of geopolymer cement paste samples increases with increasing the calcination temperature of kaolin between 600 and $700^{\circ} \mathrm{C}$ but decreases above $700^{\circ} \mathrm{C}[16]$.

Kaolin composes of kaolinite as its core mineral component with handful of secondary minerals, including anatase, quartz, dickite, halloysite and nacrite. In strong alkaline environments, dissolution rate and behaviour of quartz and kaolin differs as quartz has lower reactivity that kaolin. Structural characteristic of dehydrated halloysite, dickite, and nacrite differ while having similar chemical composition as kaolinite. Kaolinite has a sheet structure while halloysite has a tubular structure. In terms of hydroxyl groups, kaolinite has two out of the three hydroxyl groups contribute to the bond while, bonding between layers of dickite involves the collaboration of all inner-surface hydroxyl groups. It has been studied that various hydroxyl groups result in varying dehydroxylation behaviour, which may impact the reactivity of kaolin. Thus, it can be concluded that these secondary minerals present in kaolin will affect the reaction process and final properties of geopolymer. Initial research on how secondary minerals content in kaolin affects the geopolymers should be investigated due to the various types and quantity of mineral composition in kaolin [15].

Metakaolin is a dehydroxylated form of the clay mineral kaolinite. An aluminosilicate material such as kaolinite can be dissolved in an alkali-silicate solution to form a rock hard brittle ceramic. Using the proper chemistry, one can attain a high strength material that can set as little as a few hours at room temperature [16]. During the last few decades, fly ash, slag, kaolinite, mine tailings, etc. are used as raw materials to synthesize geopolymers. Among them kaolinite is the most common raw material due to its relatively purer components. In its raw form, kaolin can react and form a fully hardened geopolymer [15-16].

However, metakaolin is often used due to increased reactivity over raw kaolinite. Metakaolin obtain from calcination or dehydroxylation of kaolin clay at $500-900{ }^{\circ} \mathrm{C}$. This removes chemically bonded water and change a large portion of the octahedral coordinated 
aluminum which is found in kaolin to four and five-fold configuration [16]. Kong et al. [32] reported that $\mathrm{S} / \mathrm{L}$ ratio of 0.8 gave nearly optimum strength and provided good workability. Higher S/L ratio than 0.8 had very low workability and deteriorated the properties of the paste produced. Liew et al. [33] activated metakaolin pastes with alkali activation solution at $\mathrm{S} / \mathrm{L}$ ratios, by mass, ranging between 0.40 and 1.20 . The alkali activation solution was $\mathrm{Na}_{2} \mathrm{SiO}_{3} / \mathrm{NaOH}$ with different ratios. The results of bulk density and compressive strength showed that the $\mathrm{S} / \mathrm{L}$ of 0.8 gave the highest values at $\mathrm{Na}_{2} \mathrm{SiO}_{3} / \mathrm{NaOH}$ ratio of 0.20 . Weng et al. [34] studied different specific surface areas of metakaolin activated with sodium silicate and $\mathrm{NaOH}$ They concluded that higher specific surface area of metakaolin powders were characterized by quicker setting time, higher compressive strength and more homogeneous microstructure.

Dolomite. Calcium carbonate and calcium-magnesium carbonate in the form of limestone, dolomite, marl, chalk, and Oyster shell are one of the most widely utilized non-metallic materials in the industrial world. The largest use of limestone or calcium carbonate is in the cement industry where it is used as a source of $\mathrm{CaO}$ and also in the concrete industry where it is used as the primary coarse aggregate. Following the cement industry, the second largest user would be the lime industry [17].

Dolomite is relatively soft and easily crushed to a fine powder, which is used as agricultural lime ('aglime') by farmers to reduce soil acidity and also to adjust magnesium deficiencies. Study by Patel and Shah [35] reveals that value of cohesion is observed to be decreasing while angle of internal frication angle is increasing with increases in number of joints. The Normal stress is found to be decreasing as numbers of joints are increasing. Strength of jointed rock is dependent on the direction of applied loading with respect to orientation of joints [35]. In jointed rock specimen the failure is observed in terms of hair cracks surrounding the jointed rock area where as in unjointed specimen the failure is observed in terms of broken pieces of specimen. The strength of the rock specimen jointed by microfine cement is higher than the unjointed specimen. The load carrying of vertical cut specimen is higher than the horizontal cut specimen and also with increase in number of horizontal cut the load carrying capacity of specimen decreases. Observed that shear angle was dependent on confining pressure and the spacing of joint in the specimen [35].

Dolomite is equally good as limestone in neutralizing soil acidity but magnesium is also an important element itself as a plant nutrient [18]. Dolomite is a common rock-forming mineral. It is a calcium magnesium carbonate with a chemical composition of $\operatorname{CaMg}\left(\mathrm{CO}_{3}\right)_{2}$. It is the primary component of the sedimentary rock known as dolostone and the metamorphic rock known as dolomitic marble. Limestone that contains some dolomite is known as dolomitic limestone. The mineral dolomite crystallizes in the trigonal-rhombohedral system. It forms white, tan, gray, or pink crystals. Dolomite is a double carbonate, having an alternating structural arrangement of calcium and magnesium ions. It does not rapidly dissolve or effervesce (fizz) in dilute hydrochloric acid as calcite does. Crystal twinning is common [19].

\section{Chemical composition (XRF)}

Based on Table 1, fly ash, metakaolin and kaolin consists highest $\mathrm{SiO}_{2}$ and $\mathrm{Al}_{2} \mathrm{O}_{3}$ which is very important in geopolymerization process. POFA contains high $\mathrm{SiO}_{2}$ but it has low $\mathrm{Al}_{2} \mathrm{O}_{3}$ content and almost of its weight which is $21.6 \%$ was lost in ignition. Dolomite shows highest $\mathrm{CaO}$ content which is $23.0 \%$ and highest in $\mathrm{MgO}$ which is $17.2 \%$ but it has quite low $\mathrm{SiO}_{2}$ which is only $15.37 \%$. 
Table 1. The review of chemical composition of various geopolymer materials using XRF.

\begin{tabular}{|l|l|l|l|l|l|}
\hline $\begin{array}{l}\text { Chemical } \\
\text { composition }\end{array}$ & $\begin{array}{l}\text { Fly ash } \\
{[20]}\end{array}$ & $\begin{array}{l}\text { POFA } \\
{[9]}\end{array}$ & $\begin{array}{l}\text { Kaolin } \\
{[21]}\end{array}$ & $\begin{array}{l}\text { Metakaolin } \\
{[22]}\end{array}$ & $\begin{array}{l}\text { Dolomite } \\
{[23]}\end{array}$ \\
\hline $\mathrm{SiO}_{2}$ & 52.11 & 51.18 & 52.00 & 55.90 & 15.37 \\
\hline $\mathrm{Al}_{2} \mathrm{O}_{3}$ & 23.59 & 4.61 & 35.00 & 37.20 & 1.69 \\
\hline $\mathrm{Fe}_{2} \mathrm{O}_{3}$ & 7.39 & 3.42 & 1.00 & 1.70 & 0.51 \\
\hline $\mathrm{TiO}_{2}$ & 0.88 & & 0.90 & 2.40 & 0.015 \\
\hline $\mathrm{CaO}$ & 2.61 & 6.93 & $<0.05$ & 0.11 & 23.00 \\
\hline $\mathrm{MgO}$ & 0.78 & 4.02 & 0.70 & 0.24 & 17.20 \\
\hline $\mathrm{K}_{2} \mathrm{O}$ & 0.80 & 5.52 & 2.00 & 0.18 & 0.195 \\
\hline $\mathrm{Na}_{2} \mathrm{O}$ & 0.42 & 0.06 & 0.05 & 0.27 & 0.013 \\
\hline $\mathrm{SO}_{3}$ & 0.49 & & & 0.02 & \\
\hline $\mathrm{P}_{2} \mathrm{O}_{5}$ & 1.31 & & & 0.17 & 0.019 \\
\hline Loss in ignition & & 21.6 & & 0.80 & \\
\hline
\end{tabular}

The two main constituents of geopolymers are source materials and alkaline liquids. Source should be rich in silicon ( $\mathrm{Si}$ ) and aluminum (Al). These could be natural minerals such as kaolinite and clays. Alternatively, fly ash, silica fume, slag, rice-husk ash, red mud, and metakaolin, among others, could be used as source materials as byproduct materials [5].

As reported by Kroehong et al. [11], total content of $\mathrm{SiO}_{2}, \mathrm{Al}_{2} \mathrm{O}_{3}$ and $\mathrm{Fe}_{2} \mathrm{O}_{3}$ of 2 types of POFA geopolymers were $56.9 \%$ and $58.6 \%$, respectively. For insoluble material, the main chemical composition is $\mathrm{SiO}_{2}$, which is approximately $93-94 \%$.

$\mathrm{Al}_{2} \mathrm{O}_{3}$ composition is high in kaolin, metakaolin and fly ash but it is less in POFA and dolomite. Heah et al. [21] reported that $\mathrm{Al}_{2} \mathrm{O}_{3}$ composition was $35 \%$ in kaolin geopolymer while Jabiulla and Neeraja [22] reported that $\mathrm{Al}_{2} \mathrm{O}_{3}$ composition was $37.2 \%$ in metakaolin geopolymer.

\section{Environmental impacts of geopolymer}

Based on Table 2, the best performance and less environmental impact geopolymer material goes to fly ash based because it has optimum $\mathrm{SiO}_{2}$ and $\mathrm{Al}_{2} \mathrm{O}_{3}$ composition and it promotes waste reduction by reusing waste products from coal mining industry. Moreover, fly ash based geopolymer doesn't deplete natural resources like metakaolin, kaolin and dolomite based geopolymer materials.

Table 2. Various types of geopolymer based with their sources

\begin{tabular}{|l|l|l|}
\hline $\begin{array}{l}\text { Various types of geopolymer } \\
\text { based. }\end{array}$ & $\begin{array}{l}\text { Highest chemical } \\
\text { composition }\end{array}$ & \multicolumn{1}{|c|}{ Sources of raw materials } \\
\hline Fly ash [20] & $\mathrm{SiO}_{2} \& \mathrm{Al}_{2} \mathrm{O}_{3}$ & Waste product from coal mining \\
\hline Metakaolin [9] & $\mathrm{SiO}_{2} \& \mathrm{Al}_{2} \mathrm{O}_{3}$ & Natural resources \\
\hline Kaoline [21] & $\mathrm{SiO}_{2} \& \mathrm{Al}_{2} \mathrm{O}_{3}$ & Natural resources \\
\hline POFA [22] & $\mathrm{SiO}_{2}$ & $\begin{array}{l}\text { Waste product from oil palm } \\
\text { industry }\end{array}$ \\
\hline Dolomite [23] & $\mathrm{CaO}, \mathrm{MgO} \& \mathrm{SiO}_{2}$ & Natural resources \\
\hline
\end{tabular}

The use of fly ash which would otherwise be ending up in landfills in geopolymer concrete further proves that it is an environmentally friendly material. The reduced greenhouse gas emission by using Australian geopolymer products is estimated to be $44-64 \%$ compared with that of OPC [24].

The reduction in $\mathrm{CO}_{2}$ emissions for geopolymer system is due to the use of minimum processed natural minerals and industrial wastes to form the binding agents. The process of 
using this waste material as a component to produce the binder helps to mitigate the environmental problems and provides new environmentally friendly green concrete [25].

Table 3 shows the result of the environmental impact of various geopolymer materials and as reported by Habert et al. [26], the main environmental impacts that might be affected by the three types of geopolymer materials are global warming potentials and human toxicity. The environmental impacts are evaluated according to the baseline method of CML01 by Habert et al. and they evaluated 10 environmental impacts such as abiotic depletion, global warming, ozone layer depletion, fresh and marine water ecotoxicity, terrestrial ecotoxicity, human toxicity, eutrophication, acidification and photochemical oxidation.

Table 3. Environmental impact of various geopolymer materials. Adopted from Habert et al. [26].

\begin{tabular}{|l|l|l|l|}
\hline Environmental Impacts & Fly Ash & Metakaolin & $\begin{array}{l}\text { Blast Furnace Slag } \\
\text { Granulated }\end{array}$ \\
\hline $\begin{array}{l}\text { Abiotic depletions } \\
\text { (kg Sb eq.) }\end{array}$ & $1.95 \times 10^{-2}$ & $3.43 \times 10^{-2}$ & $1.21 \times 10^{-2}$ \\
\hline $\begin{array}{l}\text { Global warming potentials } \\
\text { (kg CO} 2 \text { eq.) }\end{array}$ & 2.51 & 4.32 & 1.25 \\
\hline $\begin{array}{l}\text { Ozine layer depletions } \\
\text { (kg CFC-11 eq.) }\end{array}$ & $2.43 \times 10^{-8}$ & $2.59 \times 10^{-7}$ & $2.45 \times 10^{-8}$ \\
\hline $\begin{array}{l}\text { Human toxicity } \\
\text { (kg 1,4-DB eq.) }\end{array}$ & $5.01 \times 10^{-1}$ & 1.74 & $3.99 \times 10^{-1}$ \\
\hline $\begin{array}{l}\text { Freshwater ecotoxicity } \\
\text { (kg 1,4-DB eq.) }\end{array}$ & $3.17 \times 10^{-2}$ & $5.69 \times 10^{-2}$ & $2.10 \times 10^{-1}$ \\
\hline $\begin{array}{l}\text { Marine ecotoxicity } \\
\text { (kg 1,4-DB eq.) }\end{array}$ & $2.97 \times 10^{-3}$ & $1.80 \times 10^{-4}$ & $5.20 \times 10^{-2}$ \\
\hline $\begin{array}{l}\text { Terresterial ecotoxicity } \\
\text { (kg 1,4-DB eq.) }\end{array}$ & $4.48 \times 10^{-4}$ & $1.38 \times 10^{-2}$ & $3.35 \times 10^{-3}$ \\
\hline $\begin{array}{l}\text { Photochemical oxydation } \\
\text { (kg } \mathrm{k}_{2} \mathrm{H}_{4} \text { eq.) }\end{array}$ & $6.62 \times 10^{-4}$ & $2.26 \times 10^{-3}$ & $8.39 \times 10^{-4}$ \\
\hline $\begin{array}{l}\text { Acidification } \\
\text { (kg SO } 2 \text { eq.) }\end{array}$ & $1.92 \times 10^{-2}$ & $2.42 \times 10^{-2}$ & $4.85 \times 10^{-3}$ \\
\hline $\begin{array}{l}\text { Eutrophication } \\
\text { (kg PO}{ }_{4}^{3-} \text { eq.) }\end{array}$ & $1.06 \times 10^{-3}$ & $1.87 \times 10^{-3}$ & $6.77 \times 10^{-4}$ \\
\hline
\end{tabular}

The environmental impact of these materials are calculated and compared with a $100 \%$ OPC concrete displaying an equivalent mechanical strength. For each type of geopolymer concrete, a mean impact and a standard deviation are evaluated. The impact of standard OPC concrete is considered as a reference and set at a $100 \%$ value and relative values are calculated for each mix-design [26].

This study used the Life Cycle Assessment methodology to carry out a detailed environmental evaluation of the production of geopolymer concrete. The results show that the production of most standard types of geopolymer concrete has a slightly lower impact on global warming than standard OPC concrete. However they also reveal that the production of geopolymer concrete has a higher environmental impact regarding other impact categories than global warming. This is due to the heavy effects of the production of the sodium silicate solution [26].

Geopolymer concrete made from fly ashes or granulated blast furnace slags based require less of the sodium silicate solution in order to be activated. They therefore have a lower environmental impact than geopolymer concrete made from pure metakaolin. However, when the production of fly ashes and granulated blast furnace slags is taken into account during the life cycle assessment (using either an economic or a mass allocation procedure), it appears that geopolymer concrete has a similar impact on global warming than standard concrete [26]. 
A concrete made with OPC and displaying an equivalent mechanical strength shall contain $354 \mathrm{~kg} \mathrm{~m}^{3}$ of cement [26]. The environmental impact of these mix-designs is presented in Table 4. It is obvious that the use of a sodium silicate solution is responsible for the major part of the environmental impact in the case of geopolymer concrete.

Table 4. Environmental impacts for a standard fly ash based geopolymer concrete. Adopted from Habert et al. [26].

\begin{tabular}{|l|l|l|l|l|l|l|}
\hline $\begin{array}{l}\text { Environmental } \\
\text { Impacts }\end{array}$ & $\begin{array}{l}\text { OPC } \\
\text { concrete }\end{array}$ & OPC & Fly ash & $\begin{array}{l}\text { Geopolymer } \\
\text { concrete }\end{array}$ & Na Silicate & $\begin{array}{l}\text { NaOH } \\
\text { Powder }\end{array}$ \\
\hline $\begin{array}{l}\text { Abiotic } \\
\text { depletions } \\
\text { (kg Sb eq.) }\end{array}$ & 0.61 & $5.64 \times 10^{-1}$ & $8.25 \times 10^{-2}$ & 1.19 & $7.44 \times 10^{-1}$ & $2.72 \times 10^{-2}$ \\
\hline $\begin{array}{l}\text { Global warming } \\
\text { potentials } \\
\text { (kg CO } \text { eq. }_{2}\end{array}$ & 305.9 & 299.1 & 2.14 & 168.5 & 117.8 & $3.71 \times 10^{-1}$ \\
\hline $\begin{array}{l}\text { Ozone layer } \\
\text { depletions } \\
\text { (kg CFC-11 eq.) }\end{array}$ & $8.74 \times 10^{-6}$ & $8.07 \times 10^{-6}$ & $1.37 \times 10^{-6}$ & $1.39 \times 10^{-5}$ & $9.08 \times 10^{-6}$ & $2.28 \times 10^{-6}$ \\
\hline $\begin{array}{l}\text { Human toxicity } \\
\text { (kg 1,4-DB eq.) }\end{array}$ & 18.90 & 14.26 & $6.44 \times 10-1$ & 105.4 & 82.75 & 15.84 \\
\hline $\begin{array}{l}\text { Freshwater } \\
\text { ecotoxicity } \\
\text { (kg 1,4-DB eq.) }\end{array}$ & 2.52 & 1.46 & $7.18 \times 10-2$ & 27.01 & 21.84 & 3.98 \\
\hline $\begin{array}{l}\text { Marine } \\
\text { ecotoxicity } \\
\text { (kg 1,4-DB eq.) }\end{array}$ & $9.68 \times 10^{-3}$ & $6.89 \times 10^{-3}$ & $7.86 \times 10^{-2}$ & $4.59 \times 10^{-4}$ & $3.42 \times 10^{-4}$ & $7.87 \times 10^{-3}$ \\
\hline $\begin{array}{l}\text { Terresterial } \\
\text { ecotoxicity } \\
\text { (kg 1,4-DB eq.) }\end{array}$ & 0.45 & $4.16 \times 10^{-1}$ & $6.84 \times 10^{-3}$ & 1.77 & $9.23 \times 10^{-1}$ & $7.72 \times 10^{-1}$ \\
\hline $\begin{array}{l}\text { Photochemical } \\
\text { oxydation } \\
\text { (kg C } \mathrm{H}_{4} \text { eq.) }\end{array}$ & $1.67 \times 10^{-2}$ & $1.51 \times 10^{-2}$ & $7.88 \times 10^{-4}$ & $3.65 \times 10^{-2}$ & $2.51 \times 10^{-2}$ & $7.67 \times 10^{-3}$ \\
\hline $\begin{array}{l}\text { Acidification } \\
\text { (kg SO } 2 \text { eq.) }\end{array}$ & 0.45 & $4.09 \times 10^{-1}$ & $1.35 \times 10^{-2}$ & 0.82 & $5.37 \times 10^{-1}$ & $1.78 \times 10^{-1}$ \\
\hline $\begin{array}{l}\text { Eutrophication } \\
\text { (kg PO }{ }_{4}^{3-} \text { eq.) }\end{array}$ & $6.83 \times 10^{-2}$ & $6.13 \times 10^{-2}$ & $2.01 \times 10^{-3}$ & $7.96 \times 10^{-2}$ & $5.10 \times 10^{-2}$ & $1.34 \times 10^{-2}$ \\
\hline
\end{tabular}

According to Habert et al. [26], when this type of geopolymer concrete is compared with hydraulic cement based standard concrete, it is obvious that this new type of binder allows for a strong reduction of the global warming potential. From $306 \mathrm{~kg}$ of equivalent $\mathrm{CO}_{2}$ per $\mathrm{m}^{3}$ for OPC based concrete, the geopolymer concrete releases only $169 \mathrm{~kg}$ of equivalent $\mathrm{CO}_{2}$ per $\mathrm{m}^{3}$, which represents a saving of $45 \%$. However, it is interesting to note, that this value is not so different from $\mathrm{CO}_{2}$ emission reduction reached with an improvement in cement technology efficiency, where a $50 \%$ of reduction can be achieved by using existing technologies.

Based on the study, the most vulnerable environmental impacts affected by the materials of fly ash geopolymer and OPC are global warming potentials, human toxicity and terrestrial ecotoxicity. Fly ash geopolymer concrete and OPC concrete are recorded to be causing the abiotic depletions which are limestones and other lithospheric resources while the least impact goes to fly ash since fly ash consumption into geopolymer processing will reduce the environmental pollution.

As reported by Habert et al. [26], the most impactful material for global warming potential is OPC concrete with $305.9 \mathrm{~kg} \mathrm{CO}_{2}$ eq and OPC with $299.1 \mathrm{~kg} \mathrm{CO}_{2}$ eq GWP levels. 
Geopolymer concrete at least cut the global warming impact into half which is $168.5 \mathrm{~kg} \mathrm{CO}_{2}$ eq. The least impact of this study goes to fly ash and $\mathrm{NaOH}$ powder.

If the comparison have been made between OPC concrete and fly ash based geopolymer concrete, OPC concrete shows more global warming potential than fly ash based geopolymer concrete since it cut almost half of the OPC concrete $\mathrm{CO}_{2}$ emission from its life cycle. But, fly ash based geopolymer concrete gives some other environmental impacts rather than OPC concrete but the impacts are not so serious and the impacts are listed as abiotic depletions $1.19 \mathrm{~kg} \mathrm{Sb}$ eq., human toxicity $105.4 \mathrm{~kg}$ 1,4-DB eq., freshwater ecotoxicity $27.01 \mathrm{~kg} \mathrm{1,4-DB}$ eq., terresterial ecotoxicity $1.77 \mathrm{~kg} 1,4-\mathrm{DB}$ eq. and acidification $0.82 \mathrm{kgSO}_{2} \mathrm{eq}$.

\section{Conclusion}

From the comparison review between fly ash, metakaolin, kaolin, POFA and dolomite based geopolymer materials, fly ash based geopolymer material shows the highest performance in terms of $\mathrm{SiO}_{2}$ and $\mathrm{Al}_{2} \mathrm{O}_{3}$ composition and it is the best option for environmental protection and sustainability because it apply waste reduction by reusing coal mining waste products to produce geoplymer. From the comparison review between fly ash concrete and OPC concrete, fly ash concrete based still shows positive results to the environment because it produced almost half $\mathrm{CO}_{2}$ emission lower than OPC concrete during its production, but fly ash concrete based gave some low negative impacts to the environment such as abiotic depletions, human toxicity, freshwater ecotoxicity, terresterial ecotoxicity and acidification. The impact still can be controlled and further study is needed to overcome those little impacts to make sure that geopolymer is ready to empower green technology development for the sustainable future.

This work was supported by the Center of Excellence of Geopolymer and Green Technology (CEGeogtech) and Universiti Malaysia Perlis (UniMAP) under the supervision of Assoc. Prof. Dr. Mohd Mustafa Al Bakri Abdullah.

\section{References}

1 G.P. Lodeiro, Cem. Concr. Res., 175-183 (2007)

2 N.M. Mohamed. J. Am. Sci., 6, 1381(2010)

3 N.B. Singh, B. Middendorf, Cem. Int., 6, 76 (2008)

4 S. Ahmari, X. Ren, V. Toufigh, L. Zhang, Constr. Build. Mater., 35, 718 (2012)

5 M.M.A. Abdullah, H. Kamarudin, H. Mohammed, I. Khairul Nizar, A.R. Rafiza, Y. Zarina, J. Eng. Technol. Res., 3, 1 (2011)

6 P. Chindaprasirt, T. Chareerat and V. Siricicatnanon, Cem. Concr. Compos., 29, 224 (2007)

7 N.V. Chanh, A.B. Trung, D.V. Tuan. Recent Research Geopolymer Concrete. The 3rd ACF International Conference - ACF/VCA, 1-5 (2008)

8 D.L.Y. Kong, J. G. Sanjayan, Cem. Concr. Compos., 30, 986 (2008)

9 Y. Zarina, M.M.A. Abdullah, H. Kamarudin, I. Khairul Nizar, A.R. Rafiza, Rev. Adv. Mater. Sci., 34, 37 (2013)

10 V. Subramaniam, M.A. Ngan, C. Yuen May, N.S. Nik Meriam, American Journal of Environmental Sciences, 4, 310 (2008)

11 W. Kroehong, T. Sinsiri, Jaturapitakkul. Procedia Eng., 14, 361 (2011)

12 A.R. Mohamed, K.T. Lee, N.M. Noor, N.F. Zainudin, Procedia Eng., 125, 804 (2015)

13 M.R. Wang, D.C. Jia, P. He, Y. Zhou, Mater. Lett., 64, 2551 (2010)

14 K. Rissa, T. Lepisto, K. Yrjola, Prog. Org. Coat., 55, 137 (2006) 
15 S. Ramasamy, H. Kamarudin, M.M.A. Abdullah, C.M. Ruzaidi Ghazali, A.V. Sandu, M. Binhussain, Rev. Adv. Mater. Sci., 42, 83 (2015)

16 M.A. Soleimani, R. Naghizadeh, A.R. Mirhabibi, F. Golestanifard, Iranian Journal of Materials Science \& Engineering, 9, 43 (2012)

17 B.D. Wheeler, The Rigaku Journal, 16 (1999)

18 S. Gunasekaran, G. Anbalagan, Bull. Mater. Sci., 30, 339 (2007)

19 A. Kranjc, Acta Carsologica, 35, 40 (2006)

20 M.M.A. Abdullah, H. Kamarudin, M. Binhussain, I. Khairul Nizar, A.R. Rafiza, Y. Zarina, Rev.Adv.Mater. Sci., 30, 90 (2012)

21 C.Y. Heah, M.M.A. Abdullah, M. Binhussain, M. Luqman, I. Khairul Nizar, C.M Ruzaidi, Y.M. Liew, Phys. Procedia, 22, 305 (2011)

22 S. Jabiulla, D.D. Neeraja, International Journal for Technological Research In Engineering, 1309 (2015)

23 M.A.A. Mohammed, A. Salmiaton, W.A.K.G. Wan Azlina, M.S. Mohamad Amran, Y.H. Taufiq Yap, Journal of Energy, 1 (2013)

24 B.C. McLellan, R.P. Williams, J. Lay, A. Van Riessen, G.D. Corder, J. Clean. Prod., 19, 1080 (2011)

25 S. Joshi, M. Kadu, International Journal of Environmental Science and Development, 3, 417 (2012)

26 G. Habert, J.B. 'Espinose de Lacaillerie, N. Roussel, J. Clean. Prod., 19, 1229 (2011)

27 M.I. Abdul Aleem, P.D. Arumairaj, Indian J. Sci. Technol., 5, 2299 (2012)

28 U.R. Kawade, P.A. Salunkhe, S.D. Kurhade, Int. J. Innov. Res. Sci. Eng. Technol., 135 (2014)

29 A. Goldman, A. Bentur, Cem. Concr. Res., 23, 962 (1993)

30 G.C. Isaia, A.L.G. Gastaldini, R. Moraes, Cem. Concr. Compos., 25, 69 (2003)

31 W. Tangchirapat, C. Jaturapitakkul, P. Chindaprasirt, Constr. Build. Mater., 23, 2641 (2009)

32 L.Y. Kong Daniel, G. Sanjayan Jay, Kwesi Sagoe Crentsil. Cem. Concr. Res., 37, 1583 (2007)

33 Y.M. Liew, A.M. Mustafa Al Bakri, M. Bnhussain, M. Luqman, I. Khairul Nizar, C.M. Ruzaidi, Constr. Build. Mater., 37, 440 (2012)

34 L. Weng, Kwesi Sagoe Crentsil, T. Brown, S. Song, Mater. Sci. Eng. B, 117, 163 (2005)

35 M.B. Patel, M.V. Shah, International Journal of Science Technology \& Engineering, 1, $114(2015)$ 